\title{
Design and Performance of a Novel Interface for Combined Matrix-Assisted Laser Desorption Ionization at Elevated Pressure and Electrospray Ionization with Orbitrap Mass Spectrometry
}

Citation for published version (APA):

Belov, M. E., Ellis, S. R., Dilillo, M., Paine, M. R. L., Danielson, W. F., Anderson, G. A., de Graaf, E. L., Eijkel, G. B., Heeren, R. M. A., \& McDonnell, L. A. (2017). Design and Performance of a Novel Interface for Combined Matrix-Assisted Laser Desorption Ionization at Elevated Pressure and Electrospray Ionization with Orbitrap Mass Spectrometry. Analytical Chemistry, 89(14), 7493-7501. https://doi.org/10.1021/acs.analchem.7b01168

Document status and date:

Published: 18/07/2017

DOI:

10.1021/acs.analchem.7b01168

Document Version:

Publisher's PDF, also known as Version of record

Document license:

Taverne

Please check the document version of this publication:

- A submitted manuscript is the version of the article upon submission and before peer-review. There can be important differences between the submitted version and the official published version of record. People interested in the research are advised to contact the author for the final version of the publication, or visit the DOI to the publisher's website.

- The final author version and the galley proof are versions of the publication after peer review.

- The final published version features the final layout of the paper including the volume, issue and page numbers.

Link to publication

\footnotetext{
General rights rights.

- You may freely distribute the URL identifying the publication in the public portal. please follow below link for the End User Agreement:

www.umlib.nl/taverne-license

Take down policy

If you believe that this document breaches copyright please contact us at:

repository@maastrichtuniversity.nl

providing details and we will investigate your claim.
}

Copyright and moral rights for the publications made accessible in the public portal are retained by the authors and/or other copyright owners and it is a condition of accessing publications that users recognise and abide by the legal requirements associated with these

- Users may download and print one copy of any publication from the public portal for the purpose of private study or research.

- You may not further distribute the material or use it for any profit-making activity or commercial gain

If the publication is distributed under the terms of Article $25 \mathrm{fa}$ of the Dutch Copyright Act, indicated by the "Taverne" license above,

Download date: 26 Apr. 2023 


\title{
Design and Performance of a Novel Interface for Combined Matrix- Assisted Laser Desorption lonization at Elevated Pressure and Electrospray Ionization with Orbitrap Mass Spectrometry
}

\author{
Mikhail E. Belov, ${ }^{*}{ }^{\dagger}$ Shane R. Ellis, ${ }^{\ddagger}$ Marialaura Dilillo, ${ }^{\S}$ Martin R. L. Paine, ${ }^{\ddagger}$ William F. Danielson,
} Gordon A. Anderson, ${ }^{\dagger}$ Erik L. de Graaf, ${ }^{\S}$ Gert B. Eijkel, ${ }^{\dagger}$ Ron M. A. Heeren, ${ }^{*,+}, \|_{\odot}$ and Liam A. McDonnell ${ }^{*}, \|_{\infty}$

\author{
${ }^{\dagger}$ Spectroglyph LLC, Kennewick, Washington 99338, United States \\ ${ }^{\ddagger}$ M4I, The Maastricht Multimodal Molecular Imaging Institute, Maastricht University, 6229 ER Maastricht, The Netherlands \\ ${ }^{\S}$ Fondazione Pisana per la Scienza ONLUS, 56121 Pisa, Italy
}

\section{Supporting Information}

\begin{abstract}
Matrix-Assisted Laser Desorption Ionization, MALDI, has been increasingly used in a variety of biomedical applications, including tissue imaging of clinical tissue samples, and in drug discovery and development. These studies strongly depend on the performance of the analytical instrumentation and would drastically benefit from improved sensitivity, reproducibility, and mass/spatial resolution. In this work, we report on a novel combined MALDI/ESI interface, which was coupled to different Orbitrap mass spectrometers (Elite and Q Exactive Plus) and extensively characterized with peptide and protein standards, and in tissue imaging experiments. In our approach, MALDI is performed in the elevated pressure regime (5-8 Torr) at a spatial resolution of 15-30 $\mu \mathrm{m}$, while ESI-generated ions are injected orthogonally to the interface axis. We have found that introduction of the MALDI-generated ions into an electrodynamic dualfunnel interface results in increased sensitivity characterized by a limit of detection of $\sim 400 \mathrm{zmol}$, while providing a mass measurement accuracy of $1 \mathrm{ppm}$ and a mass resolving power of 120000 in analysis of protein digests. In tissue imaging experiments, the MALDI/ESI interface has been employed in experiments with rat brain sections and was shown to be capable of visualizing and spatially characterizing very low abundance analytes separated only by $20 \mathrm{mDa}$. Comparison of imaging data has revealed excellent agreement between the MALDI and histological images.
\end{abstract}

$S^{i}$ ince its inception in the late 1990s, Matrix-Assisted Laser Desorption Ionization (MALDI) Mass Spectrometry Imaging $(\mathrm{MSI})^{1}$ has been increasingly applied to the analyses of peptides, ${ }^{2-5}$ proteins, ${ }^{6-9}$ lipids, ${ }^{10-13}$ and drugs and metabolites $^{14-16}$ in various tissue samples. MALDI MSI is capable of correlating molecular information with histology or the spatial distribution of exogenous and endogenous species, thus representing a powerful tool for a variety of diagnostic and prognostic applications in biology, pathology, medicine, and pharmacology, as described in several excellent reviews. ${ }^{17-21}$

In cancer research, MALDI MSI has been employed in a number of clinical studies with practical objectives. To name a few, these include the assessment of molecular distributions within a tumor and adjacent normal tissue in clear cell renal cell carcinoma biopsies, ${ }^{22}$ protein profiling of endoscopic biopsy samples to assist with the diagnosis of gastric cancer, ${ }^{23}$ discovery and immunohistochemical validation of putative biomarker proteins that predict disease outcome in gastric cancer after surgical resection, ${ }^{24}$ discrimination of prostate cancer tumor from normal cells by monitoring a fragment of mitogen-activated protein kinase/extracellular signal-regulated kinase kinase kinase 2 (MEKK2), ${ }^{25}$ and imaging of ovarian carcinomas (stages III and IV) and benign ovaries, with subsequent validation of the two putative biomarkers. ${ }^{26}$

In drug discovery and development, it is essential to understand in situ the behavior and localization of drug candidates as well as the correlated changes of endogenous molecules. MALDI MSI has been shown to be complementary to conventional approaches, such as whole-body autoradiography (WBA), for concurrent localization of drugs and metabolites in biological tissues. ${ }^{19}$ In particular, MALDI MSI has been used to reveal the temporal distribution of olanzapine, a neuroleptic drug used to treat psychological disorders such as schizophrenia or bipolar disorder, and its metabolites as well as the correlated regulations of endogenous proteins in response to drug administration, ${ }^{27}$ to localize the distribution of moxifloxacin in tuberculosis-infected rats and granulomatous lesions, ${ }^{28}$ and to determine the spatial distribution of the drug-

Received: March 29, 2017

Accepted: June 14, 2017

Published: June 14, 2017 
like inhibitor BDM31343, which acts as a booster for ethionamide, the antibiotic used to treat tuberculosis. ${ }^{29}$

The success of biomedical MALDI MSI studies strongly depends on the sensitivity, robustness, reproducibility, and dynamic range of the analytical instrumentation, as well as the confidence of molecular identifications. Due to their high spectrum acquisition rates and broad $m / z$ range, axial tandem Time-of-Flight (TOF-TOF) mass spectrometers are most commonly used in MALDI MSI. Current state-of-the-art TOF-TOF instrumentation enables collision induced dissociation of precursor species and is capable of providing a mass resolving power up to 50000 and a nominal mass accuracy of several parts per million at a laser repetition rate of $10 \mathrm{kHz}$ for well-defined homogeneous thin-layer samples. In practical MALDI MSI of biological tissues, variations in tissue thickness and dielectric and matrix coating result in inevitable inhomogeneity in the height profile of the biological tissue that causes variations of the acceleration field and a loss of mass accuracy (up to $100 \mathrm{ppm}$ at $\mathrm{m} / z$ 1000) throughout an MSI acquisition. These performance variations are particularly detrimental when analyzing small molecules, such as drugs, metabolites, and lipids, owing to the presence of many isobaric species in the low $m / z$ domain. ${ }^{30}$ The requirement for sampleindependent high mass measurement accuracy (5 ppm or better) and high mass resolving power (exceeding 50 000) at ultrahigh sensitivity is even more stringent when stable-isotope labeling, e.g., ${ }^{12} \mathrm{C}_{6}$ - or ${ }^{13} \mathrm{C}_{6}$-NBS (2-nitrobenzenesulfenyl), ${ }^{31}$ is combined with MALDI MSI because of the increased spectrum complexity.

Decoupling of the ionization process and mass spectrometry detection is accomplished with tandem quadrupole/orthogonal acceleration TOF instruments. ${ }^{32}$ Further improvement of analytical capability has been attained with ion mobility separation introduced between the quadrupole analyzer and the TOF separator, as implemented in a hybrid Synapt (G2-S) HDMS instrument (Waters Corp., Manchester, UK). ${ }^{33}$ Ion mobility reduces spectrum complexity by separating different classes of isobaric compounds based on their structures, e.g., lipids and peptides, and, provided sufficient IMS resolution, enables separation of fragmentation patterns of the isobaric species, resulting in higher confidence identifications of the precursor species of a given class. MALDI MSI with hybrid quadrupole-ion-mobility-TOF instruments has been applied to tissue imaging of peptides ${ }^{34}$ and lipids ${ }^{35,36}$ at a mass accuracy of $\sim 20 \mathrm{ppm}$. In the "sensitivity mode" of the Synapt G2-S instrument, a typical mass resolving power in tissue imaging of lipids was reported to be $\sim 14000$. $^{36}$

In tissue analysis, the requirement to distinguish between endogenous isobaric species and to resolve overlapping isotopic distributions is best addressed by mass spectrometers operating on the principle of image charge detection and Fourier Transform (FT)-based signal reconstruction, which include Ion Cyclotron Resonance (ICR) and Orbitrap (Thermo Fisher Scientific GmbH, Bremen, Germany) mass spectrometers. MALDI-FTICR instrumentation has been successfully employed for MALDI MSI of peptides, ${ }^{37}$ proteins, ${ }^{38}$ and lipids ${ }^{39}$ as well as drugs and metabolites. ${ }^{30}$ With the introduction of a 15T MALDI FTICR (Bruker Daltonics, Billerica, MA, USA) equipped with an Apollo II dual MALDI/ESI ion source and a Smartbeam II $2 \mathrm{kHz}$ Nd:YAG (355 nm) laser, MALDI FTICR MSI at high mass resolution $(\sim 75000$ at $\mathrm{m} / z$ 5000) has also been demonstrated for smaller proteins (up to $20 \mathrm{kDa}$ ). ${ }^{40}$ Despite these successes, the very high cost of purchase and maintenance and limited MS/MS performance have constrained the potential impact of MALDI FTICR MS technological capabilities.

MALDI MSI of tissue samples with a linear quadrupolar trap (LTQ)-Orbitrap mass spectrometer has been reported by several groups. ${ }^{16,41}$ Using a home-built atmospheric pressure scanning microprobe matrix assisted laser desorption/ionization (AP-SMALDI) imaging source with a nitrogen laser $(\lambda=$ $337 \mathrm{~nm}$, LTB MNL-106, LTB, Berlin, Germany) operating at a repetition rate of $60 \mathrm{~Hz}$ and attached to an LTQ Orbitrap Discovery (Thermo Fisher Scientific GmbH, Bremen, Germany), imaging of neuropeptides at a spatial resolution of $5 \mu \mathrm{m}$ has been reported. ${ }^{42}$

An important parameter influencing the efficiency of the MALDI process is the background pressure. In early MALDI MSI studies, the effect of background pressure in the sample area was studied with an LTQ. ${ }^{43}$ An increase in pressure in the collisional quadrupole region from $10^{-6}$ Torr to 0.17 Torr resulted in a 3-fold increase in the signal-to-noise $(\mathrm{S} / \mathrm{N})$ ratio of the protonated lipid signals. It is noteworthy that a further increase in pressure in the LTQ is limited by a decrease in the vacuum effective potential, $E_{\mathrm{RF}_{\text {_vac }}}$ due to the collisional damping term, $\gamma:^{44}$

$$
\gamma=\frac{E_{\mathrm{RF}}}{E_{\mathrm{RF} \_\mathrm{vac}}}=\frac{\omega^{2} \tau^{2}}{1+\omega^{2} \tau^{2}}
$$

where $\omega$ is the angular frequency of the confining RF field and $\tau$ is the collisional relaxation time. An increase in the RF amplitude at the collisional quadrupole, required to compensate for the collisional damping effect, would result in arcing and RF drive instability.

The other end of the explored range for sample ionization is atmospheric pressure, ${ }^{45}$ which allows for the analysis of biological samples in their most native form and without the need for dehydration. ${ }^{20}$ However, AP-MALDI ${ }^{45}$ (or APSMALDI $^{16,42}$ ) has lower intrinsic sensitivity due to ion losses in the narrow (typically, $400-600 \mu \mathrm{m}$ i.d.) inlet capillary, and ions larger than approximately $m / z 3000$ are detected with very low sensitivity.

In this work, we report on a novel dual MALDI/ESI interface for direct coupling to either a hybrid LTQ-Orbitrap Elite MS or a Q Exactive MS (both manufactured by Thermo Fisher Scientific $\mathrm{GmbH}$, Bremen, Germany). With this approach, MALDI MSI is performed at a user-defined elevated pressure (EP), in the range of 3 to 10 Torr, while ESI is conducted at atmospheric pressure orthogonally to the interface axis. MALDI-generated ions are captured by the RF field of an electrodynamic ion funnel, thus yielding drastically increased sensitivity at higher pressures as compared to multipole ion guides and efficient collisional dampening of excess internal energy gained during the MALDI process.

\section{EXPERIMENTAL SECTION}

All experiments were performed with modified Q Exactive Plus and Orbitrap Elite mass spectrometers (Thermo Fisher Scientific $\mathrm{GmbH}$, Bremen, Germany) using a novel interface for MALDI imaging at elevated pressure (EP) and direct ESI infusion in nano- and microflow regimes. The dual functionality EP MALDI/ESI interface was employed instead of the commercial Stacked Ring Ion Guide (SRIG), as shown in Figure 1. The interface exhibits a number of advanced features, including (i) an orthogonal injection of electrospray-generated 


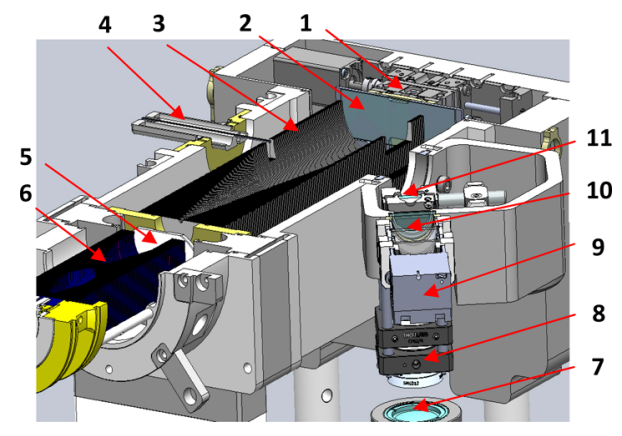

Figure 1. Engineering drawing of the MALDI/ESI interface to an Orbitrap MS. The following components are shown: 1, translation stages; 2, MALDI slide; 3, Higher Pressure Ion (HPF) funnel; 4, inlet capillary housing; 5, slide valve; 6, Ion Funnel Trap (IFT); 7, 20× 355 $\mathrm{nm}$ laser beam expander; 8, $200 \mathrm{~mm}$ UV-grade fused silica lens; 9, CCD camera; 10, long pass colored filter; $11,355 \mathrm{~nm} 45^{\circ}$ laser line mirror.

ions into the radio frequency (RF) field of a dual ion funnel interface, which encompasses a Higher Pressure Funnel, HPF, and an Ion Funnel Trap, IFT, separated by a slide valve; (ii) a Diode Pumped Solid State (DPSS) laser assembly with ultraviolet (UV) collimating and focusing optics as well as sample visualization optical system; (iii) a sample positioning system, incorporating two vacuum motorized stages.

Different components of the system, including the dual ion funnel interface, DPSS laser assembly, dual sample positioning system, and data acquisition and processing software, as well as sample preparation protocols are described in detail in the Supporting Information. The MALDI/ESI injector represents a single assembly with MALDI and ESI components mounted orthogonally and independently of each other. As a result, switching between different ESI sources as well as disengaging/ coupling the interface from/to the mass spectrometer have no effect on laser focusing and alignment. Extensive characterization of the interface performance in the ESI mode has been described elsewhere. ${ }^{46,47}$ In this work, we report on the instrument performance in the MALDI mode. The ESI inlet has been routinely used prior to MALDI experiments for tuning and calibration of the mass spectrometer. All the components of the interface have been optimized to attain high sensitivity, high speed of analysis, high mass accuracy, and high spatial/ mass resolution followed by rigorous evaluation of the instrument performance in the EP MALDI MSI experiments.

\section{RESULTS}

Interface Characterization. In the EP MALDI mode, the performance of the MALDI/ESI injector has been characterized with a variety of samples, including standards, such as peptides and proteins, as well as lipids from biological tissues. Figure 2a shows the analyte signals as a function of the MALDI extraction voltage that is the potential difference between the voltages applied to the conductive microscope slide and the HPF entrance electrode. Two peptides of a bovine serum albumin (BSA) tryptic digest, (K)YLYEIAR(R) and (K)TVMENFVAFVDK $(\mathrm{C})$, at a protein concentration of $1 \mathrm{pmol} /$ $\mu \mathrm{L}$ were chosen as analytes in these experiments. The HPF entrance electrode has been decoupled from the RF waveform to minimize any RF-field trapping effect. This resulted in a DConly electric field in the region between the sample slide and the funnel operating at a pressure of 6 Torr. Such a pressure regime is characterized by the drag force exerted on the charged molecules by gas, which must be counterbalanced by the directional force due to the electric field (analogous to an ion mobility spectrometer). With an increase in the extraction voltage, the analyte signal intensities were found to increase and reach a plateau at $40-50 \mathrm{~V}$, which indicates nearly complete capture of the MALDI ions by the funnel interface. Figure $2 b$ demonstrates signal-to-noise $(\mathrm{S} / \mathrm{N})$ ratios of the same analytes as a function of the injection time into the Curved Liner Trap (CLT). The $\mathrm{S} / \mathrm{N}$ ratios increased linearly up to $80-100 \mathrm{~ms}$ followed by $\mathrm{S} / \mathrm{N}$ saturation at longer injection times. Saturation in $\mathrm{S} / \mathrm{N}$ points to the filling of the CLT with MALDI-generated ions up to its capacity and determines the linear dynamic range of the instrument. Figure $2 \mathrm{c}$ depicts the dependence of the analyte signals on the HPF pressure. To maintain the optimum operating conditions downstream of the HPF region, the pressure in the IFT region was maintained at 1.3 Torr independently of pressure regulation in the HPF region. The MALDI extraction voltage was also increased with an increase in pressure to maintain a similar Townsend's number of $1.5 \mathrm{Td}$ in the region between the conductive microscope slide and HPF entrance electrode. The pressure dependence study has revealed a decrease in the analyte signal intensities with an increase in the HPF pressure above 8 Torr. This effect has been attributed to the possible ion losses at elevated pressures through the HPF lateral slot used for introduction of the laser beam.

Analysis of Standards. Figure 3a shows mass spectra of MALDI standards, such as bradykinin at concentrations ranging from $1 \mathrm{fmol} / \mu \mathrm{L}$ to $1 \mathrm{pmol} / \mu \mathrm{L}$ and $1 \mathrm{pmol} / \mu \mathrm{L}$ bovine serum albumin (BSA) tryptic digest. All the data in Figure $3 a-c$ were obtained with a $355 \mathrm{~nm}$ laser and an Orbitrap Q Exactive Plus instrument. Figure $3 \mathrm{~b}$ shows the results of a limit of detection (LOD) experiment with bradykinin using the CHCA matrix. The analyte was mixed with the matrix in a proportion of $1: 2$, respectively, and a total volume of $2 \mu \mathrm{L}$ was deposited onto the ITO slide, corresponding to a deposited analyte volume of 0.66 $\mu \mathrm{L}$. The diameter of each concentration-specific sample area, $D_{\text {area }}$ was $2.8 \mathrm{~mm}$. We have analyzed seven separate areas, each at a fixed analyte concentration of $0.1,0.5,0.75,1,10,100$, and $1000 \mathrm{fmol} / \mu \mathrm{L}$, respectively. The total amount of analyte in a particular concentration area, $W_{\text {area }}(C)$, is the product of the analyte concentration and the analyte volume. For example, given the analyte concentration of $1 \mathrm{fmol} / \mu \mathrm{L}$, the total amount of analyte deposited onto the ITO slide was 660 amoles. The deposited droplets were slowly dried to ensure homogeneous distribution of the analyte in each concentration area. Signal abundances shown in Figure $3 \mathrm{~b}$ were averaged over 10 laser positions at a laser focal diameter, $D_{\text {laser }}$, of $30 \mu \mathrm{m}$. Therefore, the total amount of analyte material desorbed in the LOD experiment at each analyte concentration, $W_{\text {desorb }}(C)$, can be calculated as follows:

$$
W_{\text {desorb }}(C)=W_{\text {area }}(C) \times\left[\frac{D_{\text {laser }}}{D_{\text {area }}}\right]^{2} \times 10
$$

This study revealed a linear dependence of the signal abundance on the analyte concentration in the log-log scale. We have also observed a signal increase proportional to an increase in the laser repetition rate. The LOD concentration at a laser repetition rate of $2 \mathrm{kHz}$ was found to be $500 \mathrm{amol} / \mu \mathrm{L}$ corresponding to a $\mathrm{S} / \mathrm{N}$ of 3 . Using eq 2 , we conclude that this concentration corresponds to a total amount of desorbed analyte of $380 \mathrm{zmol}$, which is the current detection limit of the 

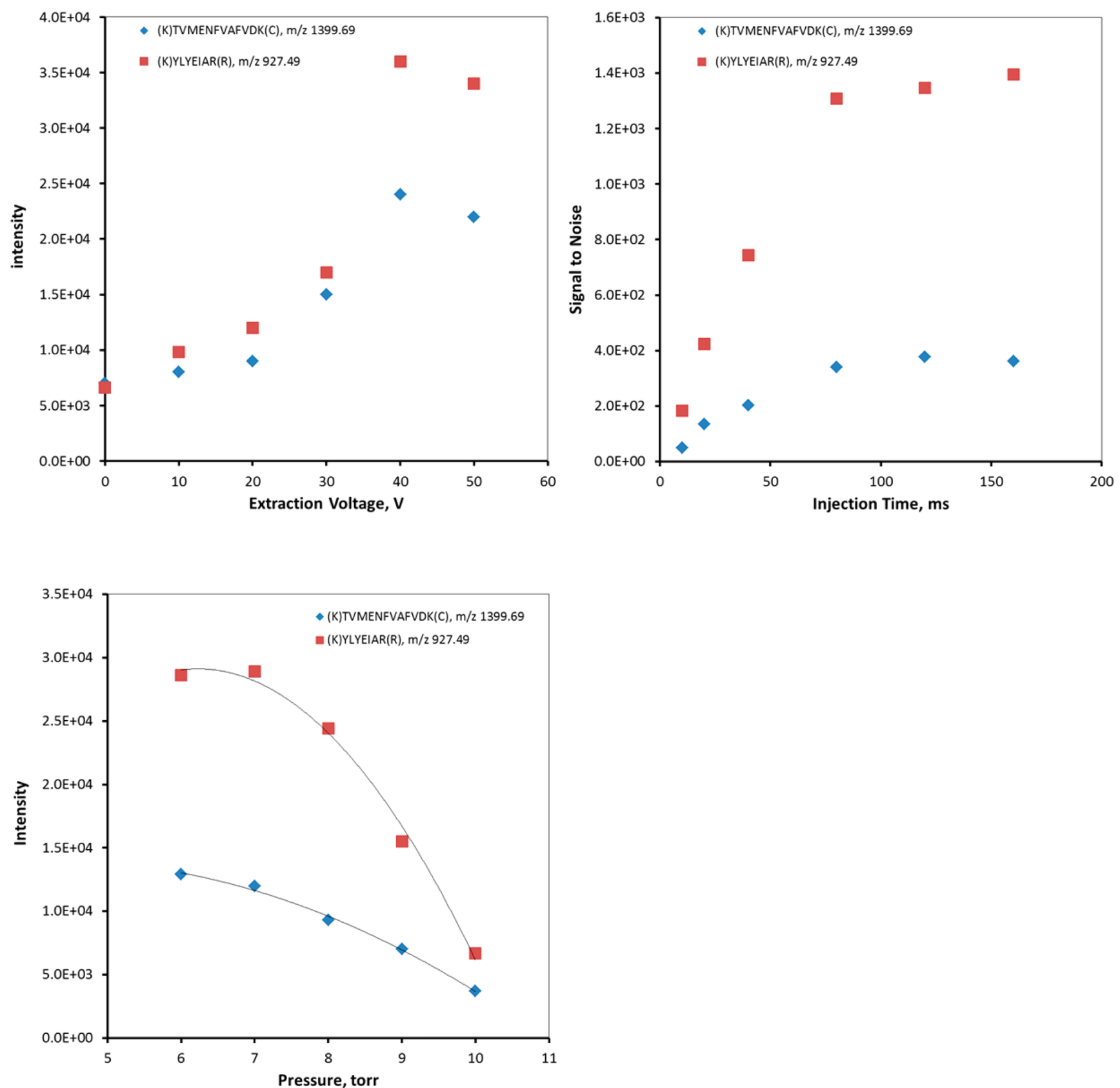

Figure 2. $(\mathrm{a}-\mathrm{c})$ Interface characterization with a $1 \mathrm{pmol} / \mu \mathrm{L}$ BSA tryptic digest. Signals of the two BSA peptides, (K)YLYEIAR(R) and (K)TVMENFVAFVDK(C), are shown at different settings. (a) Signal dependence on the MALDI extraction voltage. Pressure in the HPF region was 6 Torr; injection time was $160 \mathrm{~ms}$. (b) signal-to-noise ratio as a function of the injection time. Pressure in the HPF region was 6 Torr; MALDI extraction voltage was $50 \mathrm{~V}$. (c) Signal intensity as a function of the HPF pressure. MALDI extraction voltage and injection time were $50 \mathrm{~V}$ and 160 $\mathrm{ms}$, respectively.

Q Exactive Plus instrument equipped with our MALDI/ESI interface operating in the MALDI mode at a laser repetition rate of $2 \mathrm{kHz}$. Previous results obtained with the AP MALDI setup shortly after installation, using the same sample preparation protocol and the same $Q$ Exactive Plus mass spectrometer, found the AP MALDI limit of detection to be $\sim 100$ amol, in agreement with previously published data. ${ }^{48,49}$

BSA digest signals obtained in EP MALDI experiments were also compared to those previously obtained using a commercial Atmospheric Pressure (AP) ${ }^{42}$ MALDI source. All experiments were conducted on the same Q Exactive Plus instrument using the same sample preparation procedure. Direct comparison has revealed superior analytical capabilities of the EP MALDI approach, characterized by more than a 10-fold signal for standard peptides and BSA tryptic peptides as well as a significantly lower degree of matrix cluster formation, as illustrated in Supporting Information Figure S2 and in accord with the recently published report. ${ }^{50}$ Table S1 shows identifications of the BSA peptides detected in EP MALDI experiments. In total, 43 peptides were identified at a mass measurement accuracy of better than $1 \mathrm{ppm}$.

Figure 4a,b shows the EP MALDI signals obtained with 10 $\mathrm{pmol} / \mu \mathrm{L}$ thymosin $\beta 4$ and $10 \mathrm{pmol} / \mu \mathrm{L}$ insulin chain proteins using CHCA as the matrix. No protein signal could be detected with AP MALDI. One of the challenges to be addressed in EP MALDI experiments with intact proteins is the suppression and 

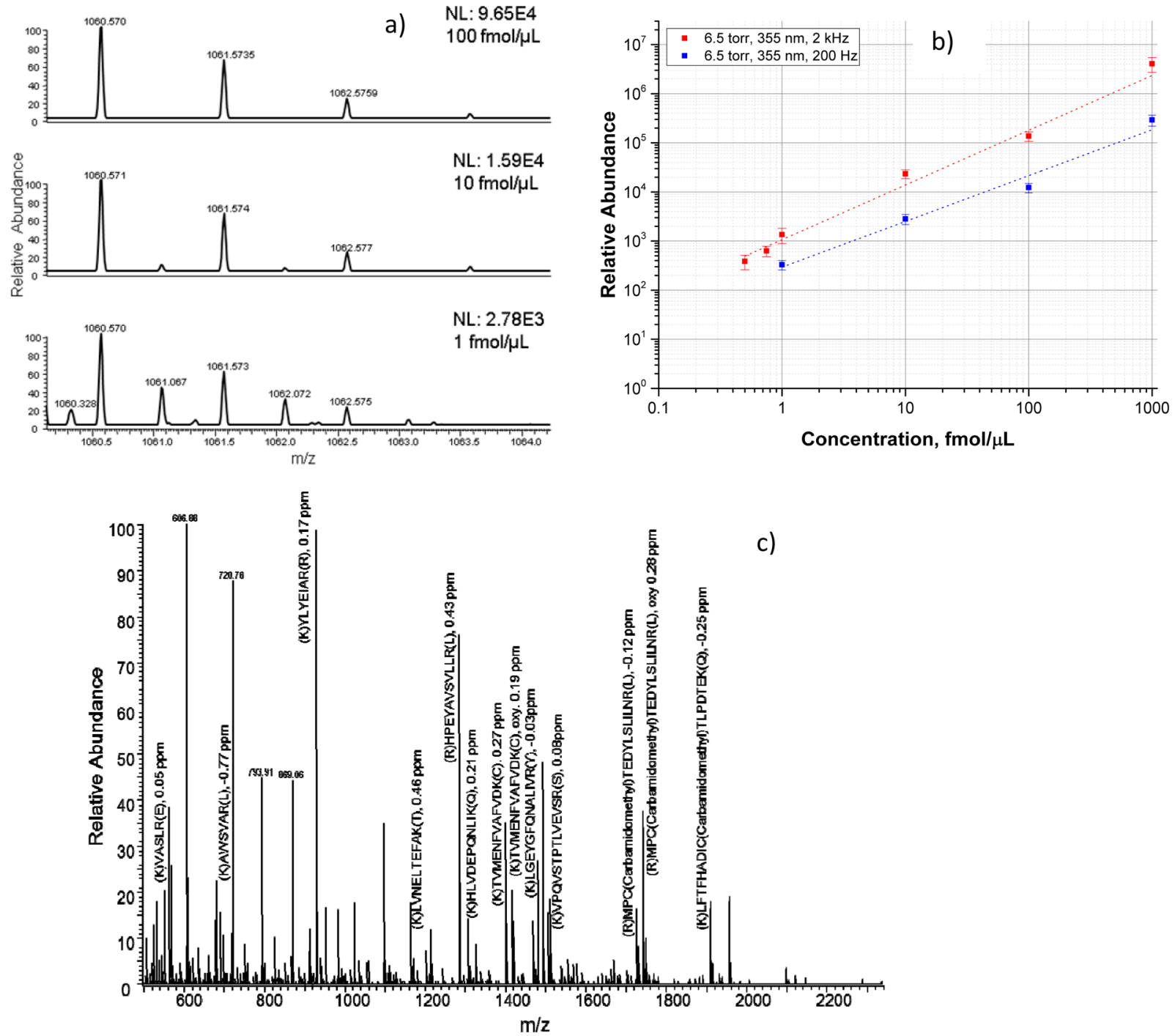

Figure 3. (a-c) EP MALDI spectra of (a) bradykinin at concentrations ranging from $100 \mathrm{fmol} / \mu \mathrm{L}$ to $1 \mathrm{fmol} / \mu \mathrm{L}$, (b) results of the limit of detection (LOD) experiment with bradykinin, and (c) EP MALDI mass spectrum of $1 \mathrm{pmol} / \mu \mathrm{L}$ bovine serum albumin (BSA) tryptic digest. All data were acquired with the Q Exactive Plus MS and the $355 \mathrm{~nm}$ DPSS laser embedded in the source. (a) Mass spectra were acquired using the following settings: AGC-controlled ion injection time, 10 microscan per spectrum, a nominal mass resolution setting of 70000 . Laser parameters: $355 \mathrm{~nm}$ wavelength, $2 \mu \mathrm{J}$ energy per pulse, $2 \mathrm{kHz}$ repetition rate, $30 \mu \mathrm{m}$ laser spot. (b) The LOD experiment was performed with bradykinin in the concentration range of $100 \mathrm{amol} / \mu \mathrm{L}$ to $1 \mathrm{pmol} / \mu \mathrm{L}$. Laser parameters: repetition rates of $200 \mathrm{~Hz}$ and $2 \mathrm{kHz}, 355 \mathrm{~nm}$ wavelength, $2 \mu \mathrm{J}$ energy per pulse. Each data point is the result of signal averaging over 10 laser positions. The LOD at a $2 \mathrm{kHz}$ repetition rate was found to be 500 amol/ $\mu \mathrm{L}$ corresponding to a $\mathrm{S} / \mathrm{N}$ of 3 . This concentration corresponds to a total amount of the desorbed analyte of $380 \mathrm{zmol}$. (c) Mass spectrum was obtained using an AGC-controlled ion injection time of $200 \mathrm{~ms}$, a scanning rate of 3.5 scans/s. and three microscans per spectrum. A total of 43 peptides have been identified at a mass accuracy better than $1 \mathrm{ppm}$. Spectrum was averaged over 10 laser sampling positions. Peptide identifications are summarized in Table S1.

removal of matrix clusters. Cluster removal has been accomplished by collisional activation of the intact protein species between the exit electrode of the Ion Funnel Trap and the inject flatapole followed by further activation in the HCD cell of the Q Exactive MS. Typical collision energies in the laboratory frame of reference used in the experiments with protein samples were 20 and $50 \mathrm{~V}$ per elementary charge, respectively.

Mass Spectrometry Imaging Experiments. A key motivation of this work has been to combine the advantages of the dual funnel interface with those of the Orbitrap analyzer for MSI of biological tissues. MSI analysis of lipids in rat brain tissue was performed to evaluate the performance of the EPMALDI source for MSI. The well-known anatomical structures of the rat brain provided the ideal sample to test the EPMALDI source's imaging capabilities. The MSI data were recorded using an Orbitrap Elite instrument operating with a nominal mass resolution of 120000 (at $\mathrm{m} / z 400$ ), a $250 \mathrm{~ms}$ ion injection time, and automatic gain control turned off. The 349 $\mathrm{nm}$ laser was operated at $1 \mathrm{kHz}$ with a pulse energy of $1.8-2 \mu \mathrm{J}$. Due to the sequential ion accumulation and FTMS acquisition steps on this instrument, stage movement to the next position was synchronized with the start of the ion injection event of the dual pressure ion trap. This ensured all ions generated at a given position were accumulated for injection into the Orbitrap.

Figure 5 shows results obtained from negative ion lipid MSI of a rat brain tissue section using a $50 \times 50 \mu \mathrm{m}^{2}$ pixel size. The summed spectrum acquired across the analyzed area is shown 

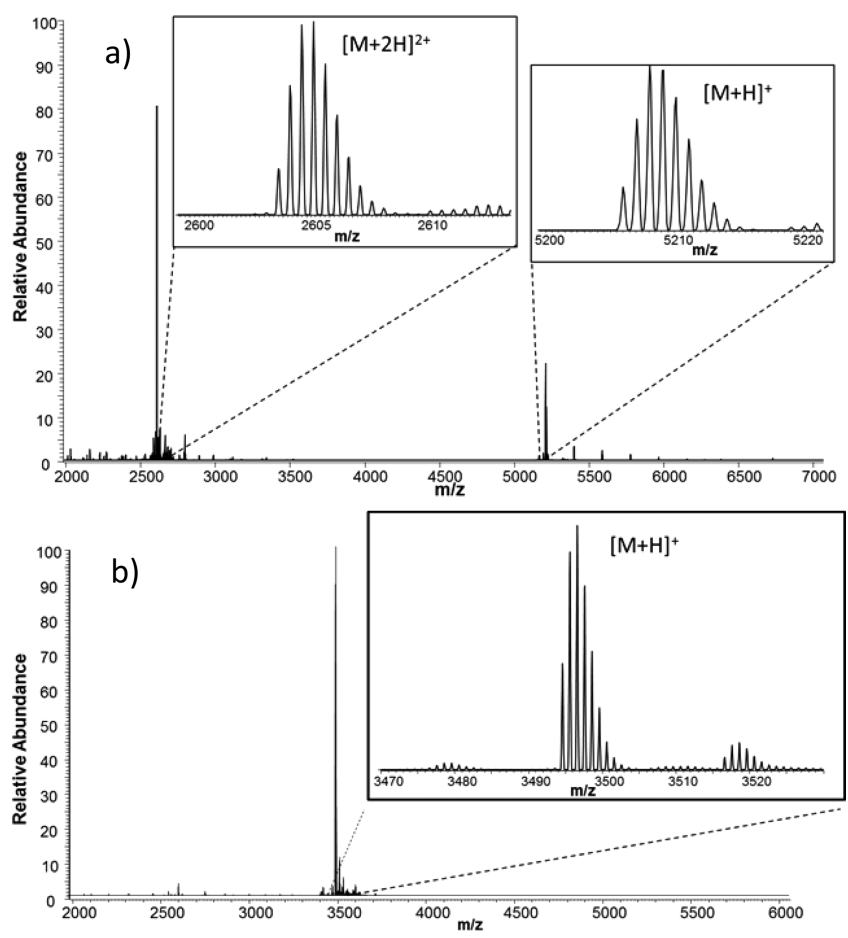

Figure 4. EP MALDI spectrum of (a) $10 \mathrm{pmol} / \mu \mathrm{L}$ thymosin $\beta 4$ protein and (b) $10 \mathrm{pmol} / \mu \mathrm{L}$ insulin chain $\mathrm{B}$ protein at the HPF pressure of 6 Torr. Signals were averaged over 10 laser sampling positions and acquired at a nominal mass resolving setting of 70000 . Laser parameters: $355 \mathrm{~nm}$ wavelength, $2 \mu \mathrm{J}$ energy per pulse, $1 \mathrm{kHz}$ repetition rate, $30 \mu \mathrm{m}$ diameter of the laser focal spot.

in Figure 5a. A variety of commonly observed phospholipid classes were detected in the $m / z 600-1000$ mass range. Above $m / z 1500$, a variety of ganglioside species, namely GM1 and $\mathrm{GD} 1$, were observed as a mixture of $[\mathrm{M}-\mathrm{H}]^{-},[\mathrm{M}-2 \mathrm{H}+\mathrm{Na}]^{-}$, and $[\mathrm{M}-2 \mathrm{H}+\mathrm{K}]^{-}$ions as previously been observed in the mouse brain. ${ }^{51,52}$ Figure $5 b$ and $c$ show MALDI MSI images of two isobaric ions observed at $m / z 834.528$ and $m / z 834.575$, assigned to the $[\mathrm{M}-\mathrm{H}]^{-}$ions of the phosphatidylserine, $\left[\mathrm{PS}\left(18: 0 \_22: 6\right)-\mathrm{H}\right]^{-}$, and the sulfatide $[\mathrm{ST}(\mathrm{d} 18: 1 / 20: 0)-\mathrm{H}]^{-}$, respectively. Structural assignments were supported by the high mass accuracy ( -1.8 and $-1.9 \mathrm{ppm}$, respectively) and collisioninduced dissociation with subsequent mass analysis in the linear ion trap. CID analysis of $m / z 834$ yielded PS(18:0_22:6)related fragment ions at $\mathrm{m} / z 747$ (loss of dehydrated serine); $m / z 419,437$, and 327 (22:6 fatty acid-related fragments); and $m / z 463,481$, and 283 (18:0 fatty acid-related fragments). CID fragment ions related to ST(d18:1/20:0) were observed at $\mathrm{m} / z$ 540 (loss of 20:0 fatty acyl as a ketene), $m / z 522$ (subsequent water loss from $m / z 540$ ), and $m / z 241$ (anhydro galactosepyranose 3 -sulfate). ${ }^{53}$ The ion distribution maps of these two isobaric species yield high contrast images with complementary distributions observed in the gray and white matter of the brain. That the observed ion images correlate well with the histology of the rat brain section confirms the high accuracy of the position-spectrum alignment used for image reconstruction.

Figure 6 shows the results of a positive mode MSI study of rat brain tissue sections and demonstrates the ability to visualize and structurally characterize very low abundance ions. MSI acquisition parameters were identical to those described above for negative ion mode. The summed spectrum acquired across a) Average Spectrum

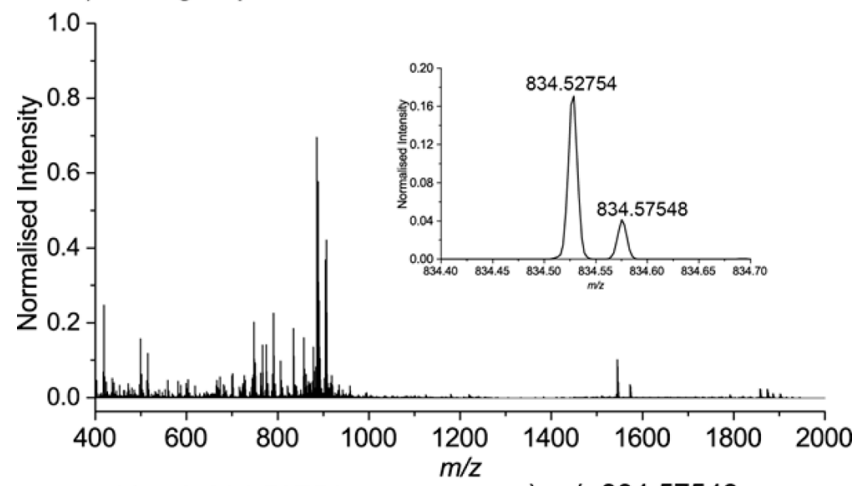

b) $m / z 834.52754$

[PS(18:0_22:6)-H]

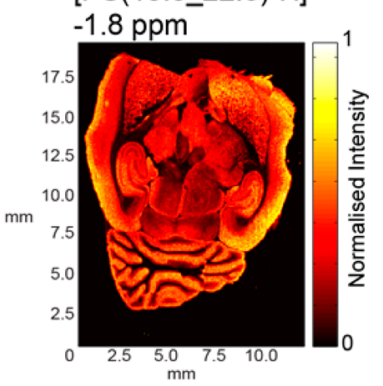

$\mathrm{c} / \mathrm{z} 834.57548$

[ST(d18:1/20:0)-H]

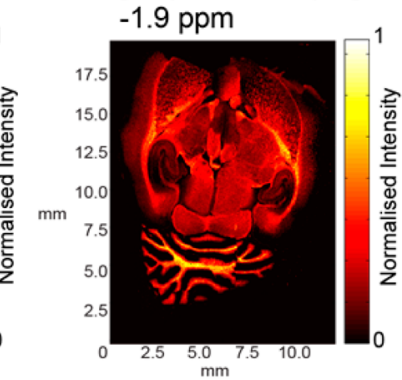

d)

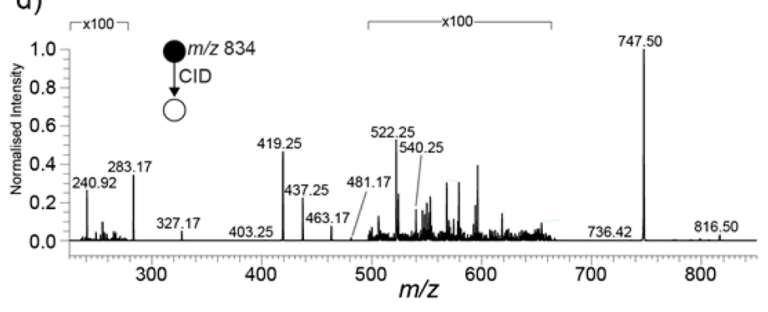

Figure 5. (a) MSI data acquired in negative ion mode from a rat brain section with $50 \times 50 \mu \mathrm{m}^{2}$ pixel size. Laser parameters used: $349 \mathrm{~nm}$ wavelength, $2 \mu \mathrm{J}$ energy per pulse, $1 \mathrm{kHz}$ repetition rate, $20 \mu \mathrm{m}$ diameter of the laser focal spot. The summed spectrum across all pixels is shown in (a) and has been normalized to the most intense lipid ion. The inset shows an enlarged view of the $\mathrm{m} / z$ 834.4-834.7 range revealing the presence of two isobaric ions. The assigned lipid structures and mass errors of these two ions as well as their ion distribution images are provided in (b) and (c). The CID spectrum acquired from $m / z 834.5$ ( $1 \mathrm{Da}$ isolation window) is shown in (d) and reveals fragmentation ions corresponding to both isobaric structures in (b) and (c). All MSI images are normalized to the total ion count. Acquisition time was $\sim 0.67 \mathrm{~s} /$ pixel.

the analyzed area is shown in Figure 6a. Almost all abundant peaks can be assigned to phosphatidylcholine (PC) and sphingomyelin (SM) related ions. The inset of Figure 6a shows a zoom of the spectrum between $\mathrm{m} / z 814.4$ and 814.8. Within this narrow $\mathrm{m} / z$ range, five low abundance peaks with relative intensities between 0.1 and $2 \%$ are observed. Figure $6 \mathrm{~b}$ shows the ion trap CID spectrum (1 Da isolation window) of this series of ions across a tissue. The high quality MS/MS spectrum demonstrates the ability to acquire a high signal-tonoise MS/MS spectrum, even for low abundance peaks from tissue. This result testifies to the high transmission efficiency of MALDI ions into the high vacuum region of the instrument. Combined with accurate mass assignments each of these five isobaric ions could be assigned to a unique lipid structure as shown in Figure $6 \mathrm{c}-\mathrm{g}$. The $\mathrm{m} / \mathrm{z} 771$ and $673 \mathrm{CID}$ fragment 

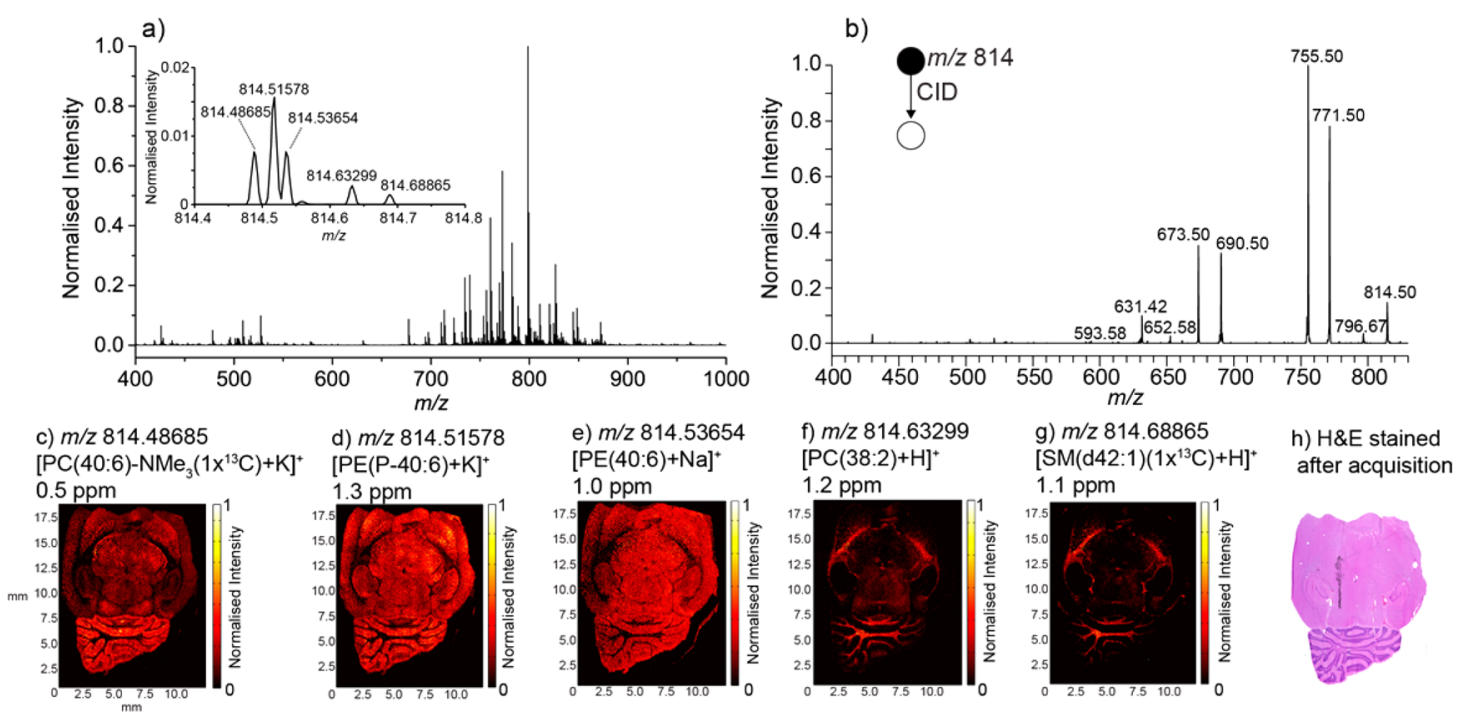

Figure 6. (a) MSI data acquired in positive ion mode from a rat brain section with $50 \times 50 \mu \mathrm{m}^{2}$ pixel size. Laser parameters: $349 \mathrm{~nm}$ wavelength, 1.8 $\mu \mathrm{J}$ energy per pulse, $1 \mathrm{kHz}$ repetition rate, $20 \mu \mathrm{m}$ diameter of the laser focal spot. The summed spectrum across all pixels is shown in a and has been normalized to the most intense lipid ion. The inset shows an enlarged view of the $\mathrm{m} / \mathrm{z}$ 814.4-834.8 range revealing the presence of five low abundance isobaric ions. (b) The corresponding CID spectrum of $m / z$ range 814-815 ( $1 \mathrm{Da}$ isolation window) providing further evidence for the presence of multiple isobaric structures. The assigned lipid structures and mass error of these five ions as well as their ion distribution images are provided in $(\mathrm{c}-\mathrm{g})$. All MSI images are normalized to the total ion count. (h) After acquisition, the matrix was removed and the tissue was stained with hematoxylin and eosin (H\&E). Acquisition time was $\sim 0.67 \mathrm{~s} /$ pixel.

ions correspond to the loss of 43 and $141 \mathrm{Da}$ of ethenamine and phosphoethanolamine, respectively, from $[\mathrm{PE}(\mathrm{P} 40: 6)+\mathrm{K}]^{+}$ and $[\mathrm{PE}(40: 6)+\mathrm{Na}]^{+}$. The $m / z 755$ and 631 fragment ions are assigned to the losses of trimethylamine $\left(\begin{array}{ll}-59 & \mathrm{Da}\end{array}\right)$ and phosphocholine, respectively, from the $[\mathrm{PC}(38: 2)+\mathrm{H}]^{+}$and $\left[\operatorname{SM}(\mathrm{d} 42: 1)\left(1 \mathrm{x}^{13} \mathrm{C}\right)+\mathrm{H}\right]^{+}$ions. Finally, fragment ions at $\mathrm{m} / z$ 690 and 652 can be assigned the subsequent loss of cyclophosphane and potassiated cyclophosphane from the isotopologue $\left[\mathrm{PC}(40: 6)-\mathrm{NMe}_{3}\left(1 \mathrm{x}^{13} \mathrm{C}\right)+\mathrm{K}\right]^{+}$ion. The associated ion images of these five ions are also provided in Figure $6 \mathrm{c}-\mathrm{g}$, along with the postacquisition $\mathrm{H} \& \mathrm{E}$ stained histological image (Figure 6h). Each isobaric ion image reveals a unique spatial distribution. The clear observation of sharp, high contrast images, even for ions of only $0.1 \%$ relative abundance, demonstrates the high dynamic range attained with the EPMALDI system. Finally, to evaluate the ability for higher spatial resolution imaging, we have analyzed the cerebellum of a rat brain with a $15 \mu \mathrm{m}$ step size. Selected ion images and a representative single pixel spectrum are provided in Supporting Information Figure $\mathrm{S} 3$ and demonstrate the high $\mathrm{S} / \mathrm{N}$ obtainable under such conditions.

\section{CONCLUSIONS}

For the past two decades, MALDI MSI has been extensively developed and used for biomedical research by many groups. It has also been recognized that further technological improvements are needed to incorporate MALDI MSI imaging as an indispensable and versatile tool into, e.g., routine pathological practice and the drug discovery and development pipeline. ${ }^{54}$

In this work, we report on a novel interface for combined MALDI MSI at elevated pressure and concurrent ESI using Orbitrap mass spectrometers. We have demonstrated that once directly injected into a dual-funnel interface operating at a userdefined pressure in the range of 5-8 Torr, MALDI-generated ions of lipids, peptides, and proteins could be efficiently transmitted into the high vacuum regions of different Orbitrap systems and then detected at high mass measurement accuracy (1-2 ppm) and high mass resolving power (120000). Our experiments with peptides have shown that the limit of detection of EP MALDI is at the level of $\sim 400 \mathrm{zmol}$, when using a laser repetition rate of $2 \mathrm{kHz}$, a laser wavelength of 355 $\mathrm{nm}$, and a laser energy of $2 \mu \mathrm{J}$ in a $5 \mathrm{~ns}$ pulse. In experiments with rat brain tissue sections, we have shown that EP-MALDI MSI is performed with high sensitivity and dynamic range at a spatial resolution of $15-20 \mu \mathrm{m}$ and provides highly confident localization of biomolecular ions separated in mass by just 10$20 \mathrm{mDa}$. Direct comparison of the MALDI images of rat brain sections with histological images confirmed excellent agreement between the MSI data and histology. Our studies over the past year have shown that the use of the novel combined MALDI/ ESI interface with Orbitrap mass spectrometers offers high sensitivity, high mass and spatial resolution, and high mass accuracy and represents a robust and reproducible approach for MSI of complex biological tissues.

\section{ASSOCIATED CONTENT}

Supporting Information

The Supporting Information is available free of charge on the ACS Publications website at DOI: 10.1021/acs.analchem.7b01168.

Extended Experimental Section, Figures S1-S3, Table S1 (PDF)

\section{AUTHOR INFORMATION}

\section{Corresponding Authors}

*E-mail: mbelov@spectroglyph.com.

*E-mail: r.heeren@maastrichtuniversity.nl.

*E-mail: 1.a.mcdonnell@fpscience.it.

ORCID 웅

Mikhail E. Belov: 0000-0002-7353-4789

Ron M. A. Heeren: 0000-0002-6533-7179 
Liam A. McDonnell: 0000-0003-0595-9491

\section{Author Contributions}

"Authors contributed equally.

\section{Notes}

The authors declare no competing financial interest.

\section{ACKNOWLEDGMENTS}

This work has been made possible with the financial support of the LINK program of the Dutch province of Limburg. Maastricht University gratefully acknowledges financial support by ITEA and RVO by means of project numbers ITEA151003/ ITEA 14001.

\section{REFERENCES}

(1) Caprioli, R. M.; Farmer, T. B.; Gile, J. Anal. Chem. 1997, 69, 4751-4760.

(2) Stoeckli, M.; Staab, D.; Staufenbiel, M.; Wiederhold, K.-H.; Signor, L. Anal. Biochem. 2002, 311, 33-39.

(3) Groseclose, M. R.; Andersson, M.; Hardesty, W. M.; Caprioli, R. M. J. Mass Spectrom. 2007, 42, 254-262.

(4) Chen, R. B.; Jiang, X. Y.; Prieto Conaway, M. C.; Mohtashemi, I.; Hui, L. M.; Viner, R.; Li, L. J. J. Proteome Res. 2010, 9, 818-832.

(5) Altelaar, A. F. M.; Taban, I. M.; McDonnell, L. A.; Verhaert, P. D. E. M.; de Lange, R. P. J.; Adan, R. A. H.; Mooi, W. J.; Heeren, R. M. A.; Piersma, S. R. Int. J. Mass Spectrom. 2007, 260, 203-211.

(6) Chaurand, P.; Luetzenkirchen, F.; Spengler, B. J. Am. Soc. Mass Spectrom. 1999, 10, 91-103.

(7) Andersson, M.; Groseclose, M. R.; Deutch, A. Y.; Caprioli, R. M. Nat. Methods 2008, 5, 101-108.

(8) Lagarrigue, M.; Becker, M.; Lavigne, R.; Deininger, S.-O.; Walch, A.; Aubry, F.; Suckau, D.; Pineau, C. Mol. Cell. Proteomics 2011, 10, M110.005991.

(9) McDonnell, L. A.; Corthals, G. L.; Willems, S. M.; van Remoortere, A.; van Zeijl, R. J. M.; Deelder, A. M. J. Proteomics 2010, 73, 1921-1944.

(10) Chaurand, P.; Cornett, D. S.; Angel, P. M.; Caprioli, R. M. Mol. Cell. Proteomics 2011, 10, O110.004259.

(11) Angel, P. M.; Spraggins, J. M.; Baldwin, H. S.; Caprioli, R. M. Anal. Chem. 2012, 84, 1557-1564.

(12) Touboul, D.; Brunelle, A. Methods Mol. Biol. 2015, 1203, 41-48.

(13) Murphy, R. C.; Hankin, J. A.; Barkley, R. M. J. Lipid Res. 2008, 50, S317-S322.

(14) Reyzer, M. L.; Hsieh, Y.; Ng, K.; Korfmacher, W. A.; Caprioli, R. M. J. Mass Spectrom. 2003, 38, 1081-1092.

(15) Stoeckli, M.; Staab, D.; Schweitzer, A. Int. J. Mass Spectrom. 2007, 260, 195-202.

(16) Römpp, A.; Guenther, S.; Takats, Z.; Spengler, B. Anal. Bioanal. Chem. 2011, 401, 65-73.

(17) Chughtai, K.; Heeren, R. M. A. Chem. Rev. 2010, 110, 32373277.

(18) Seeley, E. H.; Caprioli, R. M. Trends Biotechnol. 2011, 29, 136143.

(19) Oppenheimer, S. R.; Drexler, D. M. Bioanalysis 2012, 4, 95112.

(20) Römpp, A.; Spengler, B. Histochem. Cell Biol. 2013, 139, 759783.

(21) Bodzon-Kulakowska, A.; Suder, P. Mass Spectrom. Rev. 2016, 35, 147-169.

(22) Oppenheimer, S. R.; Mi, D.; Sanders, M. E.; Caprioli, R. M. J. Proteome Res. 2010, 9, 2182-2190.

(23) Kim, H. K.; Reyzer, M. L.; Choi, I. J.; Kim, C. G.; Kim, H. S.; Oshima, A.; Chertov, O.; Colantonio, S.; Fisher, R. J.; Allen, J. L.; Caprioli, R. M.; Green, J. E. J. Proteome Res. 2010, 9, 4123-4130.

(24) Balluff, B.; Rauser, S.; Meding, S.; Elsner, M.; Schöne, C.; Feuchtinger, A.; Schuhmacher, C.; Novotny, A.; Jütting, U.; Maccarrone, G.; Sarioglu, H.; Ueffing, M.; Braselmann, H.;
Zitzelsberger, H.; Schmid, R. M.; Höfler, H.; Ebert, M. P.; Walch, A. Am. J. Pathol. 2011, 179, 2720-2729.

(25) Cazares, L. H.; Troyer, D.; Mendrinos, S.; Lance, R. A.; Nyalwidhe, J. O.; Beydoun, H. A.; Clements, M. A.; Drake, R. R.; Semmes, O. J. Clin. Cancer Res. 2009, 15, 5541-5551.

(26) El Ayed, M.; Bonnel, D.; Longuespée, R.; Castellier, C.; Franck, J.; Vergara, D.; Desmons, A.; Tasiemski, A.; Kenani, A.; Vinatier, D.; Day, R.; Fournier, I.; Salzet, M. Med. Sci. Monit. 2010, 16, BR233-245.

(27) Khatib-Shahidi, S.; Andersson, M.; Herman, J. L.; Gillespie, T. A.; Caprioli, R. M. Anal. Chem. 2006, 78, 6448-6456.

(28) Prideaux, B.; Dartois, V.; Staab, D.; Weiner, D. M.; Goh, A.; Via, L. E.; Barry, C. E., III; Stoeckli, M. Anal. Chem. 2011, 83, 2112-2118.

(29) Bonnel, D.; Legouffe, R.; Willand, N.; Baulard, A.; Hamm, G.; Deprez, B.; Stauber, J. Bioanalysis 2011, 3, 1399-1406.

(30) Cornett, D. S.; Frappier, S. L.; Caprioli, R. M. Anal. Chem. 2008, $80,5648-5653$.

(31) Ueda, K.; Katagiri, T.; Shimada, T.; Irie, S.; Sato, T.-A.; Nakamura, Y.; Daigo, Y. J. Proteome Res. 2007, 6, 3475-3483.

(32) Loboda, A. V.; Krutchinsky, A. N.; Bromirski, M.; Ens, W.; Standing, K. G. Rapid Commun. Mass Spectrom. 2000, 14, 1047-1057.

(33) Pringle, S. D.; Giles, K.; Wildgoose, J. L.; Williams, J. P.; Slade, S. E.; Thalassinos, K.; Bateman, R. H.; Bowers, M. T.; Scrivens, J. H. Int. J. Mass Spectrom. 2007, 261, 1-12.

(34) Stauber, J.; MacAleese, L.; Franck, J.; Claude, E.; Snel, M.; Kaletas, B. K.; Wiel, I. M. V. D.; Wisztorski, M.; Fournier, I.; Heeren, R. M. A. J. Am. Soc. Mass Spectrom. 2010, 21, 338-347.

(35) Djidja, M.-C.; Claude, E.; Snel, M. F.; Scriven, P.; Francese, S.; Carolan, V.; Clench, M. R. J. Proteome Res. 2009, 8, 4876-4884.

(36) Kettling, H.; Vens-Cappell, S.; Soltwisch, J.; Pirkl, A.; Haier, J.; Müthing, J.; Dreisewerd, K. Anal. Chem. 2014, 86, 7798-7805.

(37) Taban, I. M.; Altelaar, A. F. M.; Burgt, Y. E. M. v. d.; McDonnell, L. A.; Heeren, R. M. A.; Fuchser, J.; Baykut, G. J. Am. Soc. Mass Spectrom. 2007, 18, 145-151.

(38) Spraggins, J. M.; Rizzo, D. G.; Moore, J. L.; Rose, K. L.; Hammer, N. D.; Skaar, E. P.; Caprioli, R. M. J. Am. Soc. Mass Spectrom. 2015, 26, 974-985.

(39) Jones, E. E.; Powers, T. W.; Neely, B. A.; Cazares, L. H.; Troyer, D. A.; Parker, A. S.; Drake, R. R. Proteomics 2014, 14, 924-935.

(40) Spraggins, J. M.; Rizzo, D. G.; Moore, J. L.; Noto, M. J.; Skaar, E. P.; Caprioli, R. M. Proteomics 2016, 16, 1678-1689.

(41) Perdian, D. C.; Lee, Y. J. Anal. Chem. 2010, 82, 9393-9400.

(42) Guenther, S.; Römpp, A.; Kummer, W.; Spengler, B. Int. J. Mass Spectrom. 2011, 305, 228-237.

(43) Garrett, T. J.; Prieto-Conaway, M. C.; Kovtoun, V.; Bui, H.; Izgarian, N.; Stafford, G.; Yost, R. A. Int. J. Mass Spectrom. 2007, 260, 166.

(44) Tolmachev, A. V.; Chernushevich, I. V.; Dodonov, A. F.; Standing, K. G. Nucl. Instrum. Methods Phys. Res., Sect. B 1997, 124, $112-119$.

(45) Doroshenko, V. M.; Laiko, V. V.; Taranenko, N. I.; Berkout, V. D.; Lee, H. S. Int. J. Mass Spectrom. 2002, 221, 39-58.

(46) Belov, M. E.; Damoc, E.; Denisov, E.; Compton, P. D.; Horning, S.; Makarov, A. A.; Kelleher, N. L. Anal. Chem. 2013, 85, 1116311173 .

(47) Ben-Nissan, G.; Belov, M. E.; Morgenstern, D.; Levin, Y.; Dym, O.; Arkind, G.; Lipson, C.; Makarov, A. A.; Sharon, M. Anal. Chem. 2017, 89, 4708-4715.

(48) Miller, C. A.; Yi, D.; Perkins, P. D. Rapid Commun. Mass Spectrom. 2003, 17, 860-868.

(49) Schneider, B. S.; Lock, C.; Covey, T. R. J. Am. Soc. Mass Spectrom. 2005, 16, 176-182.

(50) Moskovets, E.; Misharin, A.; Laiko, V.; Doroshenko, V. M. Methods 2016, 104, 21-32.

(51) Sugiura, Y.; Shimma, S.; Konishi, Y.; Yamada, M. K.; Setou, M. PLoS One 2008, 3, e3232.

(52) Zarei, M.; Bindila, L.; Souady, J.; Dreisewerd, K.; Berkenkamp, S.; Müthing, J.; Peter-Katalinić, J. A. J. Mass Spectrom. 2008, 43, 716725 . 
(53) Hsu, F.-F.; Turk, J. J. Am. Soc. Mass Spectrom. 2004, 15, 536554.

(54) Castellino, S. Bioanalysis 2012, 4, 2549-2551. 